\title{
CONDUCTIVITY AND STRUCTURE OF SUPERIONIC COMPOSITE $(\mathrm{AgI})_{0.6}\left(\mathrm{NaPO}_{3}\right)_{0.4}$
}

\author{
E.Kartini ${ }^{1}$, T.Sakuma ${ }^{2}$, A.Purwanto ${ }^{1,3}$, T.Kamiyama ${ }^{3}$, M.F. Collins ${ }^{4}$ \\ ${ }^{1}$ R\&D Center for Materials Science and Technology, National Nuclear Energy Agency, \\ (BATAN), Indonesia \\ ${ }^{2}$ Department of Physics, Ibaraki University, Mito, Japan \\ ${ }^{3}$ Neutron Science Laboratory, KEK, Tsukuba, Japan \\ ${ }^{4}$ Department of Physics, McMaster University, Hamilton, ON, Canada
}

\begin{abstract}
CONDUCTIVITY AND STRUCTURE OF SUPERIONIC COMPOSITE $(\mathrm{AgI})_{0.6}\left(\mathrm{NaPO}_{3}\right)_{0.4}$. Superionic conductors are of considerable interest from both application and fundamental points of view. Superionic solid electrolytes can be used for batteries, fuel cells and sensors. We have used melt quenching to make a new superionic composite $(\mathrm{AgI})_{0.6}\left(\mathrm{NaPO}_{3}\right)_{0.4}$ which exhibits an ionic conductivity of about $2 \times 10^{-4} \mathrm{~S} / \mathrm{cm}$ at ambient temperature. The conductivity of crystalline $\mathrm{AgI}$ and $\mathrm{NaPO}_{3}$ glass are lower of orders of magnitude. $(\mathrm{AgI})_{0.6}\left(\mathrm{NaPO}_{3}\right)_{0.4}$ is a composite material containing both crystalline and glass phases. The paper presents the conductivity as a function of temperature measured by impedance spectroscopy and the crystal structure performed by a high resolution powder diffractometer, VEGA at the Neutron Science Laboratory (KENS), KEK, Japan.
\end{abstract}

Keywords: Conductivity, Neutron Diffraction, composite, superionic

Corresponding Author: Dr. E. Kartini, R\&D Center for Material Science and Technology, National Nuclear Energy Agency, Puspiptek Serpong, Tangerang 15314, Indonesia. Fax: +62-021-7560926 ; E-mail : kartini@,centrin.net.id

\section{INTRODUCTION}

There is increasing demand on developing new solid electrolytes for practical applications such as solid state batteries, smart windows, fuel cells and sensor devices. Many research efforts have been tried to fulfill the need by seeking new materials that meet the criteria for useful solid electrolytes. Some of those criteria are as follows: high room-temperature ionic conductivity, transference number close to unity and temperature stability [1]. Crystalline $\mathrm{AgI}$ and $\mathrm{Ag}_{2} \mathrm{~S}$ are only usable as practical ionic conductors in their high temperature phases well above room temperature. AgI has three different crystalline phases [2-5]. At room temperature the predominant phase is $\gamma$-AgI phase with the zinc-blende face-centered-cubic structure $\mathrm{F}-43 \mathrm{~m}$, though usually some $\beta-\mathrm{AgI}$ is also present with the wurtzite hexagonal structure $\mathrm{P}_{3} m m c$. $\beta$-AgI becomes the more stable phase above $384 \mathrm{~K}$ though coexistence of the phases may still occur. Both phases transform to body-centered-cubic $\alpha$-AgI at $420 \mathrm{~K}$ with an increase of conductivity by orders of magnitude to $10^{-2} \mathrm{~S} / \mathrm{cm}$. $\alpha-A g I$ meets the requirement of having high ionic conductivity, but the problem is that it is not 
stable at ambient temperature, while most appliances work at ambient temperature.

The direction of much research is how to modify AgI so that it has high ionic conductivity at room temperature. Several methods have been developed for example by mixing AgI with another component that may be crystalline, polymer or an oxide-glass [6-10]. One idea is to attempt to compress the $\alpha \rightarrow \beta$ AgI transition temperature in order to stabilize $\alpha-\mathrm{AgI}$ at room temperature. Tatsumisago and his coworkers [6-8] have shown evidence of the $\alpha-\mathrm{AgI}$ frozen on the $\mathrm{AgI}-\mathrm{Ag}_{2} \mathrm{O}-\mathrm{B}_{2} \mathrm{O}_{3}$ glasses at room temperature by very fast quenching rate (twin roller). In this composite glass, the structure of the precipitates corresponds to a mixture of $\alpha-\mathrm{AgI}$ and $\beta-\mathrm{AgI}$ which exhibits ionic conductivity of about $\sim 10^{-2} \mathrm{~S} / \mathrm{cm}$. Another idea is to put the silver into a glassy material. Work in this area has been reviewed by Collins and Kartini [9]. Kartini et al. [10] in their work on $(\mathrm{AgI})_{\mathrm{x}}\left(\mathrm{AgPO}_{3}\right)_{1-\mathrm{x}}$ composite glasses have shown that a precipitate occurs for the compositions $\mathrm{x}=0.7$ and $\mathrm{x}=0.8$, but for $\mathrm{x} \leq 0.5$ the samples are entirely glasses. The precipitate in $(\mathrm{AgI})_{0.7}\left(\mathrm{AgPO}_{3}\right)_{0.3}$ is the mixture $\gamma$-and $\beta$-AgI $[11,12]$. Frozen $\alpha-\mathrm{AgI}$ was not found but the conductivity of this composite is better than $10^{-2} \mathrm{~S} / \mathrm{cm}$, which is high enough for the material to be used in practical applications.

In this work we investigate a new superionic composite-glass AgI$\mathrm{NaPO}_{3}$ made by mixing $\mathrm{AgI}$ with sodium phosphate $\mathrm{NaPO}_{3}$ glass and quenching from the melt [13]. The properties of $(\mathrm{AgI})_{0.7}\left(\mathrm{NaPO}_{3}\right)_{0.3}$, such as the $\mathrm{x}$-ray diffraction pattern, the thermal properties and the ionic conductivity, have been studied by Kartini et al. [13]. The results show that there is an increase of conductivity of the composite by three orders magnitude compared with the pure crystalline $\mathrm{AgI}$ and the base glass $\mathrm{NaPO}_{3}$. Purwanto et al. $[14,15]$ in their recent works, have studied in more detail the structure of the $(\mathrm{AgI})_{0.7}\left(\mathrm{NaPO}_{3}\right)_{0.3}$ and $(\mathrm{AgI})_{0.8}\left(\mathrm{NaPO}_{3}\right)_{0.2}$ by neutron diffraction and found them to be composite materials containing both glass and crystal components. The crystal component of $(\mathrm{AgI})_{0.8}\left(\mathrm{NaPO}_{3}\right)_{0.2}$ contains $70 \% \gamma$-AgI and $30 \% \beta$-AgI while for $(\mathrm{AgI})_{0.7}\left(\mathrm{NaPO}_{3}\right)_{0.3}$ it contains $53 \% \gamma$-AgI and $47 \% \quad \mathrm{Ag}_{5} \mathrm{IP}_{2} \mathrm{O}_{7}$. The disappearance of $\beta$-AgI and a replacement by $\mathrm{Ag}_{5} \mathrm{IP}_{2} \mathrm{O}_{7}$ was not expected [14].

At room temperature both $\mathrm{Ag}_{5} \mathrm{IP}_{2} \mathrm{O}_{7}[16]$ and $\beta$-AgI [8] have low ionic conductivity at about $10^{-6} \mathrm{~S} / \mathrm{cm}$. The base glass $\mathrm{NaPO}_{3}$ has even lower conductivity of about $10^{-8} \mathrm{~S} / \mathrm{cm}$. On the other hand, the ionic conductivities for $(\mathrm{AgI})_{0.7}\left(\mathrm{NaPO}_{3}\right)_{0.3}$ and $(\mathrm{AgI})_{0.8}\left(\mathrm{NaPO}_{3}\right)_{0.2}$ are between $10^{-4}$ and $10^{-3} \mathrm{~S} / \mathrm{cm}$ at room temperature. In order to have a greater understanding of these materials and to extend the series, measurements of the conductivity and of the structure have been performed on $(\mathrm{AgI})_{0.6}\left(\mathrm{NaPO}_{3}\right)_{0.4}$. This paper describes these measurements and compares them with the previous studies of $(\mathrm{AgI})_{0.7}\left(\mathrm{NaPO}_{3}\right)_{0.3}$ and $(\mathrm{AgI})_{0.8}\left(\mathrm{NaPO}_{3}\right)_{0.2}$. 


\section{EXPERIMENTS}

The superionic composite $(\mathrm{AgI})_{0.6}\left(\mathrm{NaPO}_{3}\right)_{0.4}$ was prepared by mixing appropriate amounts of $\mathrm{AgI}\left(99.9 \%\right.$ Aesar), $\mathrm{NH}_{4} \mathrm{H}_{2} \mathrm{PO}_{4}$ (Koso Chemical 98\%) and $\mathrm{NaNO}_{3}$ (Sterm Chemical 98\%). The mixture was ground, placed in a porcelain crucible, and then heated up to $850{ }^{\circ} \mathrm{C}$ for three hours. The molten mixture was poured into a liquid-nitrogen cooled brass cylindrical tube with one end closed. The sample preparation was done at the Laboratory of Advanced Materials Division, R\&D Center for Materials Science and Technology, BATAN, Indonesia.

Powder samples for electrical conductivity measurements were made by pressing between silver electrodes at $700 \mathrm{~kg} / \mathrm{cm}^{2}$ into cylindrical pellets $1.3 \mathrm{~cm}$ in diameter and approximately $0.2 \mathrm{~cm}$ in thickness. The impedance measurements were performed using a KOKUYO LCZ meter at $1 \mathrm{kHz}$ at the Physics Department, Ibaraki University, Japan, in the temperature range between $200 \mathrm{~K}$ and $500 \mathrm{~K}$.

The neutron diffraction experiment was performed at room temperature using the high resolution powder diffractometer VEGA at the Neutron Science Laboratory (KENS), KEK, Japan. The powder diffraction was measured with the sample in a vanadium holder with diameter of $0.5 \mathrm{~cm}$ and height of $5.0 \mathrm{~cm}$. The refinement was done for the neutron data using RIETAN2000T, which uses profile function optimized for the VEGA diffractometer.

\section{RESULTS AND DISCUSSIONS}

\section{Ionic Conductivity}

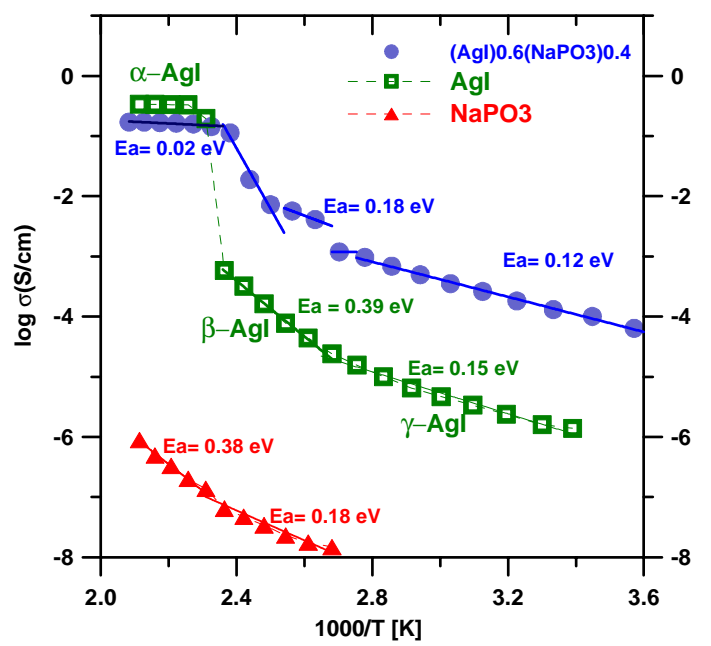

Figure 1. Arrhenius plot of the electrical conductivity of $(\mathrm{AgI})_{0.6}\left(\mathrm{NaPO}_{3}\right)_{0.4}$ superionic composite, $\mathrm{NaPO}_{3}$ glass and crystalline AgI. 
Figure 1 shows the electrical conductivity of $(\mathrm{AgI})_{0.6}\left(\mathrm{NaPO}_{3}\right)_{0.4}$ compared with $\mathrm{NaPO}_{3}$ glass and crystalline AgI. Normally, the conductivity of superionic conducting materials is found to obey the Arrhenius law fairly well throughout the glass region,

$$
\sigma_{=} \sigma_{\mathrm{o}} \exp \left(-\mathrm{E}_{\mathrm{a}} / k_{B} \mathrm{~T}\right)
$$

where $E_{a}$ is the activation energy for motion, $k_{B}$ is Boltzmann's constant and $\sigma_{0}$ is the pre-exponential factor. Linear regions are apparent in the Arrhenius plots of Figure 1, but there are also sudden changes in the conductivity or in its temperature derivative. Below about $380 \mathrm{~K}$ the plots are all linear and follow the Arrhenius law. The conductivity of $(\mathrm{AgI})_{0.6}\left(\mathrm{NaPO}_{3}\right)_{0.4}$ falls into four different regions that can be related to the phases of AgI. The small discontinuity at about $384 \mathrm{~K}$ is due to the phase transition from $\gamma$-AgI to $\beta$-AgI. Close to $420 \mathrm{~K}$ there is a larger discontinuity in the conductivity due to the $\beta$-AgI to $\alpha-\operatorname{AgI}$ phase transition. The conductivity curves mimic the behavior of crystalline AgI, where the two transitions occur at about $383 \mathrm{~K}$ and $420 \mathrm{~K}$, respectively. Unlike the $\beta \rightarrow \alpha \mathrm{AgI}$ phase transition temperature that changes abruptly, the transition from $\gamma-\mathrm{AgI}$ to $\beta-\mathrm{AgI}$ is less strongly marked. The conductivity is almost two orders of magnitude higher in the composite than in AgI below $380 \mathrm{~K}$, showing that it is dominated by the conductivity of the glass phase. In the $\alpha$ phase the conductivity of $\mathrm{AgI}$ is slightly higher than that of the glass.

The activation energies, $\mathrm{E}_{\mathrm{a}}$, for $(\mathrm{AgI})_{0.6}\left(\mathrm{NaPO}_{3}\right)_{0.4}$ in the temperature ranges $\mathrm{T}<380 \mathrm{~K}$ and $380 \mathrm{~K}<\mathrm{T}<420 \mathrm{~K}$ are $0.12 \mathrm{eV}$ and $0.18 \mathrm{eV}$, respectively. Just above these temperatures the conductivity increases rapidly. This change corresponds to the $\beta$-AgI to $\alpha-\mathrm{AgI}$ phase transition and above it the conductivity is similar to that of $\alpha$-AgI. There has been a transition in the major conduction path from being through the glass phase to being through the precipitate. The activation energy of the composite becomes of the same order as in $\alpha-\mathrm{AgI}$, about $0.02 \mathrm{eV}$, corresponding to high ionic mobility.

Table 1 shows the ionic conductivities for $(\mathrm{AgI})_{\mathrm{x}}\left(\mathrm{NaPO}_{3}\right)_{1-\mathrm{x}}$ with $\mathrm{x}=0.6,0.7$ and 0.8 ; and $\mathrm{NaPO}_{3}$ and $\mathrm{AgI}$. The conductivity at room temperature of the three composites $(\mathrm{AgI})_{0.6}\left(\mathrm{NaPO}_{3}\right)_{0.4},(\mathrm{AgI})_{0.7}\left(\mathrm{NaPO}_{3}\right)_{0.3}$, and $(\mathrm{AgI})_{0.8}\left(\mathrm{NaPO}_{3}\right)_{0.2}$ are $1.32 \times 10^{-4} \mathrm{~S} / \mathrm{cm}, 2.14 \times 10^{-4} \mathrm{~S} / \mathrm{cm}$ and $1.86 \times 10^{-4}$ $\mathrm{S} / \mathrm{cm}$, respectively, while for $\mathrm{NaPO}_{3}$ and $\mathrm{AgI}$ it is $1.5 \times 10^{-8} \mathrm{~S} / \mathrm{cm}$ and $1.62 \times 10^{-6} \mathrm{~S} / \mathrm{cm}$, respectively. The conductivity of the composites is of larger order magnitude than in the corresponding base glass, $\mathrm{NaPO}_{3}$ and the pure crystalline AgI. 
Table 1. The conductivity of $(\mathrm{AgI})_{\mathrm{x}}\left(\mathrm{NaPO}_{3}\right)_{1-\mathrm{x}}$ with $\mathrm{x}=0.6,0.7$ and 0.8 and of $\mathrm{NaPO}_{3}$ and $\mathrm{AgI}$ at several temperatures.

\begin{tabular}{|l|l|l|l|}
\hline Materials & \multicolumn{3}{|c|}{$\begin{array}{c}\text { Logarithmic conductivity } \\
\log \boldsymbol{\sigma}(\mathrm{S} / \mathrm{cm})\end{array}$} \\
\hline Temperature $\left({ }^{\mathbf{0}} \mathbf{C}\right)$ & RT & $\mathbf{1 2 0}$ & $\mathbf{1 7 0}$ \\
\hline $\mathrm{NaPO}_{3}$ & -7.85 & -7.64 & -6.69 \\
\hline$(\mathrm{AgI})_{0.6}\left(\mathrm{NaPO}_{3}\right)_{0.4}$ & -3.88 & -2.14 & -0.79 \\
\hline$(\mathrm{AgI})_{0.7}\left(\mathrm{NaPO}_{3}\right)_{0.3}$ & -3.67 & -2.13 & -0.70 \\
\hline$(\mathrm{AgI})_{0.8}\left(\mathrm{NaPO}_{3}\right)_{0.2}$ & -3.73 & -2.14 & -0.64 \\
\hline $\mathrm{AgI}$ & -5.79 & -4.11 & -0.48 \\
\hline
\end{tabular}

\section{Neutron Diffraction of $(\mathrm{AgI})_{0.6}\left(\mathrm{NaPO}_{3}\right)_{0.4}$ at room temperature}

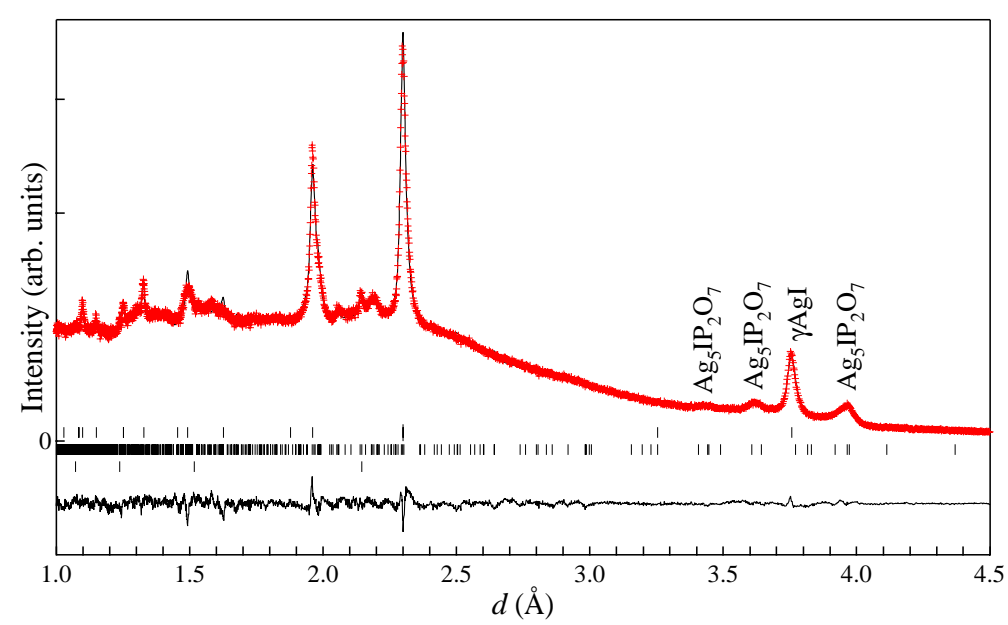

Figure 2. The neutron diffraction pattern from $(\mathrm{AgI})_{0.6}\left(\mathrm{NaPO}_{3}\right)_{0.4}$ and the refinement fit. The reflection markers from the top are $\gamma$-AgI, $\mathrm{Ag}_{5} \mathrm{IP}_{2} \mathrm{O}_{7}$ and the vanadium holder, respectively.

Figure 2 shows details from refinements of the neutron diffraction pattern of $(\mathrm{AgI})_{0.6}\left(\mathrm{NaPO}_{3}\right)_{0.4}$. The strongest Bragg peaks belong to $\gamma-\mathrm{AgI}$, while the weak peak at $d=3.95 \AA$ comes from $A_{5} \mathrm{IP}_{2} \mathrm{O}_{7}$. The varying background level comes from the glass phase. 
Table 2. Refinement Result of $(\mathrm{AgI})_{0.6}\left(\mathrm{NaPO}_{3}\right)_{0.4}$

\begin{tabular}{|c|c|c|c|c|c|c|c|c|}
\hline & \multicolumn{4}{|c|}{$\begin{array}{l}\gamma \mathrm{AgI} \\
\text { Cubic F -4 } 3 \mathrm{~m} \\
\end{array}$} & \multicolumn{4}{|c|}{$\begin{array}{l}\mathrm{Ag}_{5} \mathrm{IP}_{2} \mathrm{O}_{7} \\
\text { Orthorhombic P } 22_{1} 2_{1} 2_{1}\end{array}$} \\
\hline & $x$ & $y$ & $z$ & occ & $x$ & $y$ & $z$ & occ. \\
\hline \multirow[t]{7}{*}{$\mathrm{Ag}$} & 0 & 0 & 0 & 1 & $0.602(9)$ & $0.740(8)$ & $0.670(5)$ & 1 \\
\hline & & & & & $0.277(4)$ & $0.042(4)$ & $0.613(3)$ & 1 \\
\hline & & & & & $0.982(5)$ & $0.248(6)$ & $0.013(4)$ & 1 \\
\hline & & & & & $0.371(7)$ & $0.019(11)$ & $0.726(5)$ & 0.5 \\
\hline & & & & & $0.434(9)$ & $0.852(9)$ & $0.641(5)$ & 0.5 \\
\hline & & & & & $0.100(7)$ & $0.245(9)$ & $0.823(5)$ & 0.5 \\
\hline & & & & & $0.301(10)$ & $0.219(10)$ & $1.104(5)$ & 0.5 \\
\hline I & $1 / 4$ & $1 / 4$ & $1 / 4$ & 1 & $0.912(4)$ & $0.169(5)$ & $0.824(3)$ & 1 \\
\hline \multirow[t]{2}{*}{$\mathrm{P}$} & & & & & $0.464(4)$ & $0.982(5)$ & $0.971(3)$ & 1 \\
\hline & & & & & $0.294(4)$ & $0.251(5)$ & $0.794(3)$ & 1 \\
\hline \multirow[t]{7}{*}{$\mathrm{O}$} & & & & & $0.488(5)$ & $0.920(5)$ & $0.839(3)$ & 1 \\
\hline & & & & & $0.309(3)$ & $0.818(4)$ & $0.008(3)$ & 1 \\
\hline & & & & & $0.549(4)$ & $0.768(4)$ & $0.009(3)$ & 1 \\
\hline & & & & & $0.241(4)$ & $0.027(4)$ & $0.981(3)$ & 1 \\
\hline & & & & & $0.600(4)$ & $0.222(4)$ & $0.816(3)$ & 1 \\
\hline & & & & & $0.453(5)$ & $0.399(5)$ & $0.844(2)$ & 1 \\
\hline & & & & & $0.405(5)$ & $0.230(4)$ & $0.673(3)$ & 1 \\
\hline $\begin{array}{l}\text { Lattice } \\
\text { Parameters }\end{array}$ & \multicolumn{4}{|c|}{$\mathrm{a}(\AA)=6.506(2)$} & \multicolumn{4}{|c|}{$\begin{array}{l}\mathrm{a}(\AA)=9.214(4) \\
\mathrm{b}(\AA)=7.840(3) \\
\mathrm{c}(\AA)=13.788(5)\end{array}$} \\
\hline $\begin{array}{l}\text { Mass } \\
\text { fraction }\end{array}$ & \multicolumn{4}{|c|}{$61 \%$} & \multicolumn{4}{|l|}{$39 \%$} \\
\hline $\begin{array}{l}\text { Reliability } \\
\text { Factors }\end{array}$ & \multicolumn{8}{|c|}{$\begin{array}{c}\mathrm{R}_{w p}=3.37 \% \\
\mathrm{R}_{p}=2.65 \%\end{array}$} \\
\hline
\end{tabular}

Table 2 details refined structural parameters of $(\mathrm{AgI})_{0.6}\left(\mathrm{NaPO}_{3}\right)_{0.4}$ at room temperature. The reliability factors are reasonable as can be judged from $\mathrm{R}_{w p}$ and $\mathrm{R}_{p}$ as well as from the residuals in Figure 2. The results show that the structure of the crystalline component of the composite consists of $61 \%$ and $39 \%$ mass fractions of $\gamma-\mathrm{AgI}$ and pentasilver iodide diphosphate (V) $\mathrm{Ag}_{5} \mathrm{IP}_{2} \mathrm{O}_{7}$, respectively. This result is similar to that found in $(\mathrm{AgI})_{0.7}\left(\mathrm{NaPO}_{3}\right)_{0.3}$ with $53 \%$ and $47 \%$ mass fractions of $\gamma \mathrm{AgI}$ and pentasilver iodide diphosphate (V) $\mathrm{Ag}_{5} \mathrm{IP}_{2} \mathrm{O}_{7}$, respectively as shown in Table 3. However, the crystalline component of the composite $(\mathrm{AgI})_{0.8}\left(\mathrm{NaPO}_{3}\right)_{0.2}$ contains a mixture of $70 \% \gamma-\mathrm{AgI}$ and $30 \% \beta$-AgI. Table 3 shows the refinement results for the composites $(\mathrm{AgI})_{0.6}\left(\mathrm{NaPO}_{3}\right)_{0.4},(\mathrm{AgI})_{0.7}\left(\mathrm{NaPO}_{3}\right)_{0.3}$, and $(\mathrm{AgI})_{0.8}\left(\mathrm{NaPO}_{3}\right)_{0.2}$ obtained from this experiment and earlier results $[14,15]$. The disappearance of the $\beta$-AgI and a replacement by $\operatorname{Ag}_{5} \mathrm{IP}_{2} \mathrm{O}_{7}$ at the lower composition was not expected. The change at lower composition has been described as due to oxidation of $\mathrm{PO}_{3}$ chains to $\mathrm{P}_{2} \mathrm{O}_{7}$ double tetrahedra [16]. 
Table 3. Refinement results for the composites $(\mathrm{AgI})_{0.6}\left(\mathrm{NaPO}_{3}\right)_{0.4}$ compared with $(\mathrm{AgI})_{0.7}\left(\mathrm{NaPO}_{3}\right)_{0.3}$, and $(\mathrm{AgI})_{0.8}\left(\mathrm{NaPO}_{3}\right)_{0.2}[14]$.

\begin{tabular}{|c|c|c|c|c|c|c|}
\hline Composite & \multicolumn{2}{|c|}{$(\mathrm{AgI})_{0.6}\left(\mathrm{NaPO}_{3}\right)_{0.4}$} & \multicolumn{2}{|c|}{$(\mathrm{AgI})_{0.7}\left(\mathrm{NaPO}_{3}\right)_{0.3}$} & \multicolumn{2}{|c|}{$(\mathrm{AgI})_{0.8}\left(\mathrm{NaPO}_{3}\right)_{0.2}$} \\
\hline Phase & $\begin{array}{l}\gamma \text {-AgI } \\
\text { Cubic } \\
\text { F 43m }\end{array}$ & $\begin{array}{l}\mathrm{Ag}_{5} \mathrm{P}_{2} \mathrm{O}_{7} \\
\text { Ortho } \\
\text { rhombic } \\
\mathrm{P} 2_{1} 2_{1} 2_{1}\end{array}$ & $\begin{array}{l}\gamma \text {-AgI } \\
\text { Cubic } \\
\text { F 43m }\end{array}$ & $\begin{array}{l}\mathrm{Ag}_{5} \mathrm{P}_{2} \mathrm{O}_{7} \\
\text { Ortho } \\
\text { rhombic } \\
\mathrm{P} 2_{1} 2_{1} 2_{1}\end{array}$ & $\begin{array}{l}\gamma \text {-AgI } \\
\text { Cubic } \\
\text { F 43m }\end{array}$ & $\begin{array}{l}\beta \text {-AgI } \\
\text { Hexagonal } \\
\mathrm{P} 6_{3} \mathrm{mmc}\end{array}$ \\
\hline $\begin{array}{l}\text { Lattice } \\
\text { parameter }\end{array}$ & $\begin{array}{l}\mathrm{a}(\AA)= \\
6.505(2)\end{array}$ & $\begin{array}{l}\mathrm{a}(\AA)= \\
9.214(4) \\
\mathrm{b}(\AA)= \\
7.840(3) \\
\mathrm{c}(\AA)= \\
13.788(5)\end{array}$ & $\begin{array}{l}\mathrm{a}(\AA)= \\
6.504(1)\end{array}$ & $\begin{array}{l}\mathrm{a}(\AA)= \\
9.223(4) \\
\mathrm{b}(\AA)= \\
7.829(3) \\
\mathrm{c}(\AA)= \\
13.782(5)\end{array}$ & $\mathrm{a}(\AA)=6.49(1)$ & $\begin{array}{l}\mathrm{a}(\AA)=4.588(1) \\
\mathrm{c}(\AA)=7.518(5)\end{array}$ \\
\hline Fraction & $61 \%$ & $39 \%$ & $52 \%$ & $48 \%$ & $29 \%$ & $71 \%$ \\
\hline $\begin{array}{l}\text { Reliability } \\
\text { factor }\end{array}$ & \multicolumn{2}{|c|}{$\begin{aligned} \mathrm{R}_{\mathrm{wp}} & =3.4 \% \\
\mathrm{R}_{\mathrm{p}} & =2.7 \%\end{aligned}$} & \multicolumn{2}{|c|}{$\begin{array}{c}\mathrm{R}_{\mathrm{wp}}=3.8 \% \\
\mathrm{R}_{\mathrm{p}}=2.9 \%\end{array}$} & \multicolumn{2}{|c|}{$\begin{array}{c}\mathrm{R}_{\mathrm{wp}}=4.3 \% \\
\mathrm{R}_{\mathrm{p}}=3.2 \%\end{array}$} \\
\hline
\end{tabular}

\section{CONCLUSIONS}

A new composite superionic has been successfully synthesized by melt quenching. The material contains a glass phase and two crystalline phases. The ionic conductivity of the superionic composite $(\mathrm{AgI})_{0.6}\left(\mathrm{NaPO}_{3}\right)_{0.4}$ at room temperature increases by few orders of magnitude from their crystalline $\mathrm{AgI}$ and $\mathrm{NaPO}_{3}$ glass, with the values $\sim 10^{-8} \mathrm{~S} / \mathrm{cm}$ to $\sim 10^{-3} \mathrm{~S} / \mathrm{cm}$. Another advantages of the new composite based on sodium phosphate glass, $\mathrm{AgI}-\mathrm{NaPO}_{3}$, is easy to be produced and the cost of raw material is much cheaper compared with compared with the silver phosphate glass, $\mathrm{AgI}-\mathrm{AgPO}_{3}$. In fact it is still possible to be used practically as a solid electrolyte $[9,11]$.

\section{REFERENCES}

1. R.J. CAVA, F. REIDINGER, B.J. WUENCH, Solid State Communication, 24, 411 (1977).

2. D.A. KEEN, J. Phys. Condens. Matter, 14 9, R819 (2002).

3. S. HOSHINO, T. SAKUMA, Y. FUJII, Solid State Commun, 22, 763 (1977).

4. J.S. LEE, S. ADAMS, J. MAIER, J. Phys. Chem. Solids, 61, 1607 (2000).

5. J.R.G. PATNAIK, C.S. SUNANDAN, J. Phys. Chem. Solids, 59, 1059 (1998).

6. M. TATSUMISAGO, Y. SHINKUMA, T. MINAMI, Nature, 354, 217 (1991).

7. M. TATSUMISAGO, K. OKUDA, N. ITAKURA, T. MINAMI, Solid State Ionics, 121, 193 (1999). 
8. M. TATSUMISAGO, T. SAITO, T. MINAMI, Thermochimica Acta, 280/281, 333 (1996).

9. M.F. COLLINS and E. KARTINI, in Recent Research Development of Solid State Ionics, Vol. 1, 157 (2003).

10. E. KARTINI, M.F. COLLINS, E.C. SVENSSON, T. PRIYANTO, S. YUSUF, N. INDAYANINGSIH and S.J. KENNEDY. Phys. Rev. B, 61, 1036 (2000).

11. E. KARTINI and M.F. COLLINS, Physica B $276 \&$ 278, 467 (2000).

12. E. KARTINI, Indonesian Journal of Materials Science, Vol. 1(2), 1 (2000).

13. E. KARTINI, S. PURNAMA, T. SAKUMA, D. WIDYANINGSIH, NURAINUN, Indonesian Journal of Materials Science,Vol. 4, 19 (2003).

14. A. PURWANTO, E. KARTINI, T. KAMIYAMA, A. HOSHIKAWA, S. HARJO, M.F. COLLINS, S. PURNAMA, Solid State Ionics (2004) to appear.

15. A. PURWANTO, E. KARTINI, T. KAMIYAMA, A. HOSHIKAWA, S. HARJO, M.F. COLLINS, T. SAKUMA, J. Neutron Research, Vol.13 (1-3), 169 (2005) to appear.

16. S. ADAM, A. PREUSSER, Acta Cryst. C, Cryst. Structure Commun, 55, 977 (1999). 